\title{
Expression of components of the urothelial cholinergic system in bladder and cultivated primary urothelial cells of the pig
}

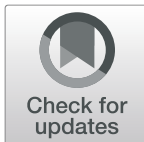

Dorothea Leonhäuser ${ }^{1}$, Jasmin Kranz $^{2}$, Regina Leidolf', Patrick Arndt ${ }^{1}$, Ulrich Schwantes ${ }^{3}$, Joachim Geyer ${ }^{2}$ and Joachim O. Grosse 1* $^{*}$

\begin{abstract}
Background: Porcine urinary bladders are widely used for uro-pharmacological examinations due to their resemblance to the human organ. However, characterisations of the porcine urothelium at the molecular level are scarce up to now. As it has become clear over the last years that this tissue plays an important role in the signaling-pathways of the bladder, we examined whether the transporter and receptor pattern (with focus on the transmitter acetylcholine) is comparable to the human urothelium. With regard to in vitro studies, we also investigated if there is a difference between the native tissue and cultivated primary urothelial cells in culture.

Methods: Urothelium from German Landrace and Göttingen Minipig bladders was collected. One part of the German Landrace tissue was used for cultivation, and different passages of the urothelial cells were collected. The actual mRNA expression of different transporters and receptors was examined via quantitative real-time PCR. These included the vesicular acetylcholine transporter (VAChT), the choline acetyl transferase (ChAT), organic cation transporters 1-3 (OCT1-3), organic anion transporting polypeptide 1A2 (OATP1A2), P-glycoprotein (ABCB1), the carnitine acetyltransferase (CarAT), as well as the muscarinic receptors 1-5 (M1-5).

Results: There is a strong qualitative resemblance between the human and the porcine urothelium with regard to the investigated cholinergic receptors, enzymes and transporters. CarAT, OCT1-3, OATP1A2 and ABCB1 could be detected in the urothelium of both pig races. Moreover, all $5 \mathrm{M}$-receptors were prominent with an emphasis on M2 and M3. VAChT and ChAT could not be detected at all. Cultures of the derived urothelial cells showed decreased expression of all targets apart from ABCB1 and CarAT.

Conclusions: Based on the expression pattern of receptors, transporters and enzymes of the cholinergic system, the porcine urinary bladder can be regarded as a good model for pharmacological studies. However, cultivation of primary urothelial cells resulted in a significant drop in mRNA expression of the targets. Therefore, it can be concluded that the intact porcine urothelium, or the whole pig bladder, may be appropriate models for studies with anticholinergic drugs, whereas cultivated urothelial cells have some limitation due to significant changes in the expression levels of relevant targets.
\end{abstract}

Keywords: Urothelium, Urinary bladder, Acetylcholine, Transporter, Muscarinic receptor, German landrace pig, Göttingen Minipig

\footnotetext{
* Correspondence: joachim.grosse1963@gmail.com

1 Department of Urology, RWTH Aachen University Hospital, Pauwelsstraße

30, 52074 Aachen, Germany

Full list of author information is available at the end of the article
}

(c) The Author(s). 2019 Open Access This article is distributed under the terms of the Creative Commons Attribution 4.0 International License (http://creativecommons.org/licenses/by/4.0/), which permits unrestricted use, distribution, and reproduction in any medium, provided you give appropriate credit to the original author(s) and the source, provide a link to the Creative Commons license, and indicate if changes were made. The Creative Commons Public Domain Dedication waiver (http://creativecommons.org/publicdomain/zero/1.0/) applies to the data made available in this article, unless otherwise stated. 


\section{Background}

Over the last years, the use of urinary pig bladders, and the pig itself as a large animal model, have become extremely popular for urological examinations. Especially pharmacological studies depend on the testing of drugs using porcine material [1-3]. This is justified on the basis that the porcine bladder closely resembles the human organ both anatomically and physiologically $[4,5]$. Nevertheless, not much research on the molecular basics has as yet been conducted which justifies unlimited use and comparison of the porcine material [5].

Some molecular examinations of detrusor and urothelial tissue have been performed on human material concerning transporters and receptors of anticholinergic drugs, such as trospium chloride, which are used as the clinical standard in the treatment of overactive bladder (OAB) [6-9]. Although it is clear that anticholinergic drugs block muscarinic (M-) acetylcholine (ACh) receptors, it is not completely understood how these drugs interact with the cellular machinery of the urothelium and the detrusor. Goepel et al. [10], as well as Sellers et al. [11], showed that muscarinic receptors M2 and M3 are prominent in porcine as well as human detrusor tissue, and in the human urothelium all five known Mreceptor subtypes are present [12-14].

Besides the M-receptors, other possible drug targets exist in the human bladder. Lips et al. [15] found proof for different transporters and enzymes responsible for synthesis and storage of $\mathrm{ACh}$ in the murine and human urothelium, including the carnitine acetyl-transferase (CarAT), whereas the classical ACh synthesising enzyme of neuronal cells, choline acetyltransferase (ChAT), seems to be absent in the urothelium. Furthermore, they demonstrated expression of the organic cation transporters OCT1-3 in the human urothelium. Interestingly, all of them are active in transporting TrCL [16]. Moreover, the solute carrier organic anion transporting polypeptide 1A2 (OATP1A2), involved in the cellular uptake of TrCL, as well as P-glycoprotein (syn. ATP-binding cassette transporter ABCB1, encoded by the multi-drug resistance gene MDR1), involved in the efflux of TrCL, are expressed in the normal urothelium [17-19]. The vesicular ACh transporter VAChT, which transports ACh in synaptic vesicles of neuronal cells, appears to be absent in the urothelium [13].

With regard to the pig as a model for pharmacological studies on anticholinergic drugs in the bladder, our aim was to determine whether these relevant transporters, enzymes and receptors are present in the porcine urothelium with the same expression pattern and to the same extent as in the human. Furthermore, their molecular stability during cell culture was to be examined.

\section{Methods}

\section{Harvest and storage of urothelial tissue and cell culture} of urothelial cells (UC)

All experiments on animals were performed in compliance with German legislation governing animal studies and the Guide for the Care and Use of Laboratory Animals (National Institutes of Health (NIH), Publication No 85-23, revised 2011). The pig urinary bladders were obtained from other working groups in our animal facility in order to reduce the number of animal experiments (3-R principle). These animal experiments were approved by the Governmental Animal Care and Use Committee (LANUV Recklinghausen). Göttingen Minipigs (GM) were about 2 years old whereas the German Landrace (GL) pigs were 6 months old. Besides the anaesthetics, no other drugs or treatments were applied to the pigs which could affect the bladder tissue. The pigs were euthanized by the original working group using $0.16 \mathrm{~g} / \mathrm{kg}$ barbiturate i.v. (Narcoren ${ }^{\oplus}$, Merial, Hallbergmoos, Germany), and the intact bladders were transported to the cell culture facility in a $37^{\circ} \mathrm{C}$ prewarmed Modified Eagle's Medium (MEM, Life Technologies, Braunschweig, Germany).

Via a Y-shaped incision, bladders from GM and GL were opened, and the urothelial tissue was carefully dissected and minced with scissors. Whole urothelial tissue of GM and one segment of GL tissue was frozen in liquid nitrogen and stored at $-80^{\circ} \mathrm{C}$. The other segment of GL tissue was used for cell culture as described previously [20]. Briefly, the urothelium was incubated in MEM containing $400 \mu \mathrm{g} / \mathrm{ml}$ collagenase (Liberase ${ }^{\oplus}$, Roche Applied Sciences, Penzberg, Germany) for $1 \mathrm{~h}$ at $37^{\circ} \mathrm{C}$. The cell suspension was then filtered, washed with MEM containing 10\% fetal calf serum (FCS, Thermo Scientific) and transferred into collagen-coated (Biochrom AG, Berlin, Germany) cell culture flasks (Nunclon ${ }^{\mathrm{T}}{ }^{\mathrm{m}}$, Thermo Scientific). Incubation of the urothelial cells (UC) for the first $24 \mathrm{~h}$ was performed in MEM containing 20\% FCS, 1\% gentamicin (PAA, GE Healthcare, Frankfurt am Main, Germany) and $1 \%$ amphotericin B (PAA). After $24 \mathrm{~h}$, the medium was changed to Keratinocyte-SFM (Life Technologies) and subsequently changed twice a week. Examination of the cells in culture was performed with a Leica DMI 4000B (Leica Microsystems GmbH, Wetzlar, Germany) with integrated software Diskus (4.80.5909, Hilgers, Technisches Büro, Königswinter, Germany). The cells were split at confluence and $1 \times 10^{6}$ cells were transferred into a new $75 \mathrm{~cm}^{2}$ flask. The remaining cells were frozen in liquid nitrogen and stored at $-80^{\circ} \mathrm{C}$.

\section{Immunohistochemical staining of tissue and cells}

Validation of the cell type was performed via immunohistochemistry. Therefore, confluent UC were detached with trypsin-EDTA (Life Technologies), washed 
with phosphate buffered saline (PBS) (Life Technologies) and fixed in $4 \%(\mathrm{w} / \mathrm{v})$ phosphate buffered formaldehyde (Merck). After further centrifugation, supernatant formaldehyde was removed and the cells were mixed with $3 \%$ (w/v) agarose (Biozym Scientific GmbH, Hessisch Oldendorf, Germany). The agarose cell-hybrids were cooled for $3 \mathrm{~min}$. in a fridge at $4{ }^{\circ} \mathrm{C}$. Native bladder tissue served as the control and was also used for staining of muscarinic receptors M2 and M3 and therefore fixed in phosphate buffered formaldehyde. The cell-hybrids and the native tissue were dehydrated, embedded in paraffin and cut into $3 \mu \mathrm{m}$ sections.

Antigen retrieval of deparaffinised sections was performed using citrate-buffer (Zytomed Systems GmbH, Berlin, Germany) in a steamer for $30 \mathrm{~min}$. Primary monoclonal and polyclonal antibodies (Table 1) were incubated for $1 \mathrm{~h}$, and secondary antibody and chromogen development (DAKO Real EnVision HRP rabbit/ mouse with $\mathrm{DAB}$ ) were applied according to the manufacturer's protocol. Counterstaining was performed using haemalaun (Merck). Staining was observed using a Leica DM6000B and integrated software Diskus (4.80.5909, Hilgers, Technisches Büro, Königswinter, Germany).

\section{Quantitative real-time polymerase chain reaction}

TriReagent (Sigma Aldrich) was used to extract RNA from cultured cells and tissues according to the manufacturer's protocol. The isolated RNA was reverse-transcribed using the SuperScript III system (Life technologies GmbH, Darmstadt, Germany). Quantitative real-time polymerase chain reaction (qRT-PCR) was performed using the TaqMan GEX Master Mix (Life Technologies). Four of the obtained assays (VAChT, OCT3, CHRM4, and CHRM5) had to be custom-made as there were no such probes available for the pig. All other TaqMan assays were ordered according to the reference numbers shown in Table 2. Glyercinaldehyde-3-phosphate-dehydrogenase (GAPDH) was used as the housekeeping gene. All assays were tested using a pig tissue cDNA panel (BioCat $\mathrm{GmbH}$, Heidelberg, Germany) prior to the initial examinations.

\section{Statistical analysis}

Cell cultures from three different animals were examined using technical triplicates. Statistical evaluation was performed using OriginPro (2017G, Origin Lab Corporation, Northampton, USA). The Shapiro-Wilks test was used to test for normal distribution, and OneWay ANOVA with the Tukey-Post Hoc test was used to determine statistical differences. Values of $p \leq 0.05$ were considered to be significant.

\section{Results}

\section{Cell culture of urothelial cells and proof of cell type}

During the cultivation period, UCs from GL could be passaged up to three times. This resulted in five samples per GL pig; the untreated bladder biopsy and four immediately consecutive passages of UCs. From these GL pig bladders and three additional GM bladders, untreated urothelial tissue samples were frozen to compare the native tissues of the different races. Immunohistochemical staining of the cells against panCK confirmed an urothelial phenotype (Fig. 1). The presence of muscarinic receptors M2 and M3, most relevant for storing and voiding of urine in the bladder, could also be visualized in the native urothelium of the German Landrace pig (Fig. 2a+b).

\section{Real-time PCR}

In general, quantitative real-time PCR expression analysis of native porcine urothelium was very similar concerning the presence of the examined transporters and receptors as in humans $[13,15]$. The enzyme CarAT and the transporter $\mathrm{ABCB} 1$ were most commonly expressed. The organic cation transporters OCT1-3, as well as OATP1A2, could be detected, but to a lesser extent (Fig. 3a). The mRNA expression for all muscarinic receptors was found in the porcine urothelium, especially M2 and M3 (Fig. 3b). $\mathrm{VaChT}$ and ChAT, as in human urothelium, were not detectable. There were no significant differences in the expression pattern between the two pig breeds.

Subsequently, it was analysed whether the enzyme/ transporter/receptor expression changed during cultivation of the porcine urothelium. In general, most of the analysed targets were down-regulated following repeated passaging of the cells. This down-regulation was most noticeable for OCT1 and OCT2 as well as M1-M3, whereas the expression level of the M4 and M5 receptors was almost maintained up to passage 3 (P3) (Fig. 4).

Table 1 Primary antibodies for immunohistochemistry

\begin{tabular}{|c|c|c|c|c|c|}
\hline Antibody & $\begin{array}{l}\text { Clone } \\
\text { number }\end{array}$ & Reactivity & Dilution & $\begin{array}{l}\text { Incubation } \\
\text { time }\end{array}$ & Company \\
\hline PanCK & AE1/AE3 & $\begin{array}{l}\text { Monoclonal mouse, anti- } \\
\text { human }\end{array}$ & $1: 300$ & $1 \mathrm{~h}$ & $\begin{array}{l}\text { Dako GmbH, Hamburg, } \\
\text { Germany }\end{array}$ \\
\hline Anti-Muscarinic Acetylcholine Receptor 2 & 31-1D1 & $\begin{array}{l}\text { Monoclonal mouse, anti- } \\
\text { human }\end{array}$ & $1: 100$ & $1 \mathrm{~h}$ & $\begin{array}{l}\text { Abcam, Cambridge, United } \\
\text { Kingdom }\end{array}$ \\
\hline $\begin{array}{l}\text { Anti-Muscarinic Acetylcholine Receptor M3 } \\
\text { antibody }\end{array}$ & - & Polyclonal rabbit, anti-pig & $1: 100$ & $1 \mathrm{~h}$ & $\begin{array}{l}\text { Abcam, Cambridge, United } \\
\text { Kingdom }\end{array}$ \\
\hline
\end{tabular}


Table 2 TaqMan gene expression assays used for real-time PCR expression analysis

\begin{tabular}{ll}
\hline Assay & Order No. \\
\hline VAChT-Pig & Custom Gene ex assay, AIWR3FN, referred to the cDNA sequence with GenBank Accession No. XM_013983446 \\
ChAT-Pig & Taqman Gene ex assay MTO, sm, Ss03391504_m1 \\
CarAT-Pig & Taqman Gene ex assay MTO, sm, Ss03389781_m1 \\
ABCB1-Pig & Taqman Gene ex assay MTO, sm, Ss03373435_m1 \\
OCT1-Pig & Taqman Gene ex assay MTO, sm, Ss03391173_m1 \\
OCT2-Pig & Taqman Gene ex assay MTO, sm, Ss03390935 \\
OCT3-Pig & Custom Gene ex assay, JD89KCA, referred to the cDNA sequence with GenBank Accession No. XM_003121106 \\
OATP1A2-Pig & Taqman Gene ex assay MTO, sm, Ss03375623_u1 \\
CHRM1-Pig & Taqman Gene ex assay MTO, sm, Ss03393581_u1 \\
CHRM2-Pig & Taqman Gene ex assay MTO, sm, Ss03383697_u1 \\
CHRM3-Pig & Taqman Gene ex assay MTO, sm, Ss03387661_u1 \\
CHRM4-Pig & Custom plus Tqmn RNA Assays, AJPADK0, referred to the cDNA sequence with GenBank Accession No. XM_003122828 \\
CHRM5-Pig & Custom plus Tqmn RNA Assays, AJN1FES, referred to the cDNA sequence with GenBank Accession No. XM_021099908 \\
GAPDH-Pig & FG, Off the shelf GX Set, Ss03374854_g1 \\
\hline
\end{tabular}

The downregulation of muscarinic receptors M2 and M3 could also be visualized by immunohistochemical staining (Fig. $2 \mathrm{c}+\mathrm{d})$.

\section{Discussion}

Previously, systematic examinations on the urothelium as an active component of the bladder storage and micturition process have been overlooked. This might be due to the fact, that this special tissue was only assumed to be a barrier with no physiological impact on the bladder function $[21,22]$. As it has become increasingly clear that the urothelium plays an essential role, it is even more important to re-examine the animal models already used for translational examinations applicable to the human bladder.

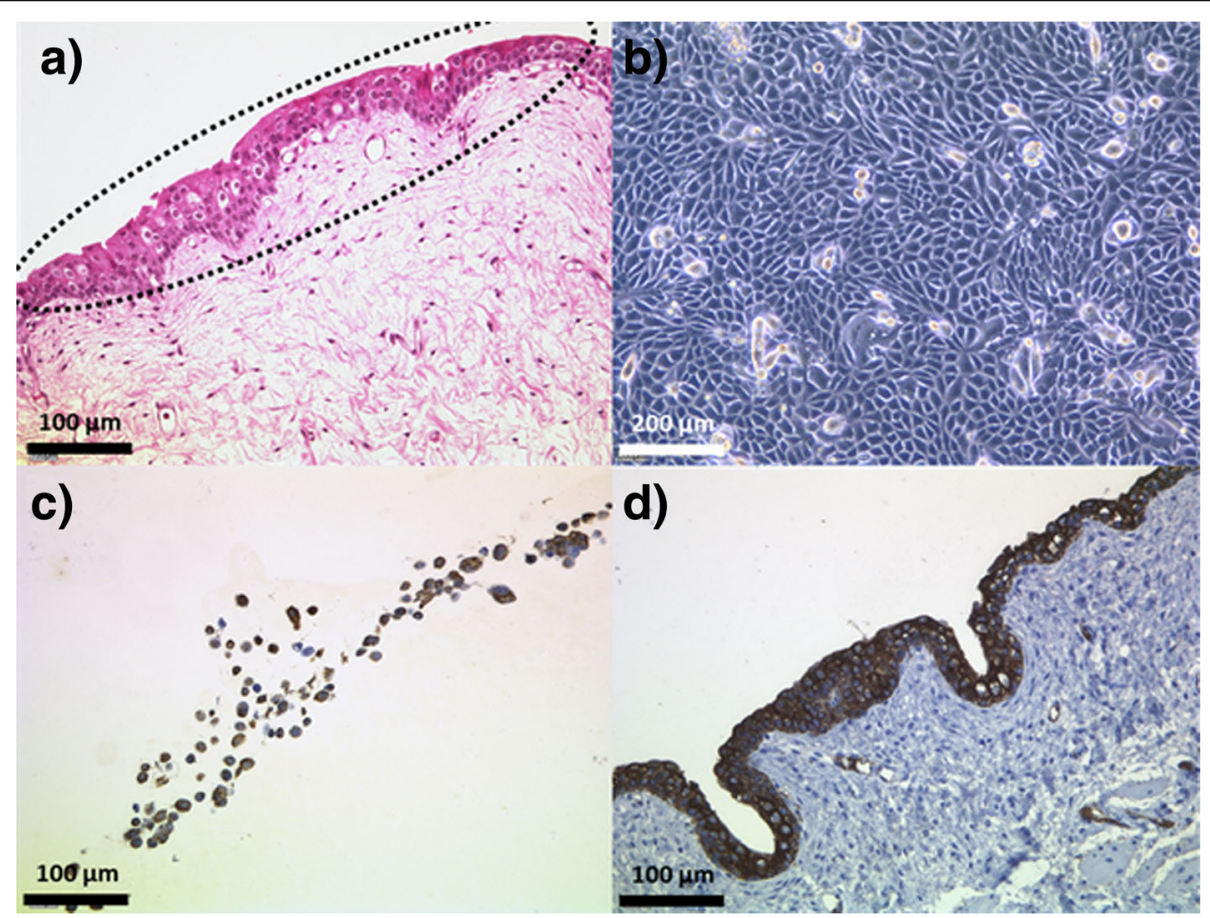

Fig. 1 Isolation of urothelial cells from German Landrace pig urothelium. a Urothelial layer which was dissected from the underlying lamina propria (HE staining). b Urothelial cells in culture at confluence. $\mathbf{c}$ Immunostaining of UCs with panCK embedded in agarose. $\mathbf{d}$ Positive control of porcine urothelium, immunostained with panCK 


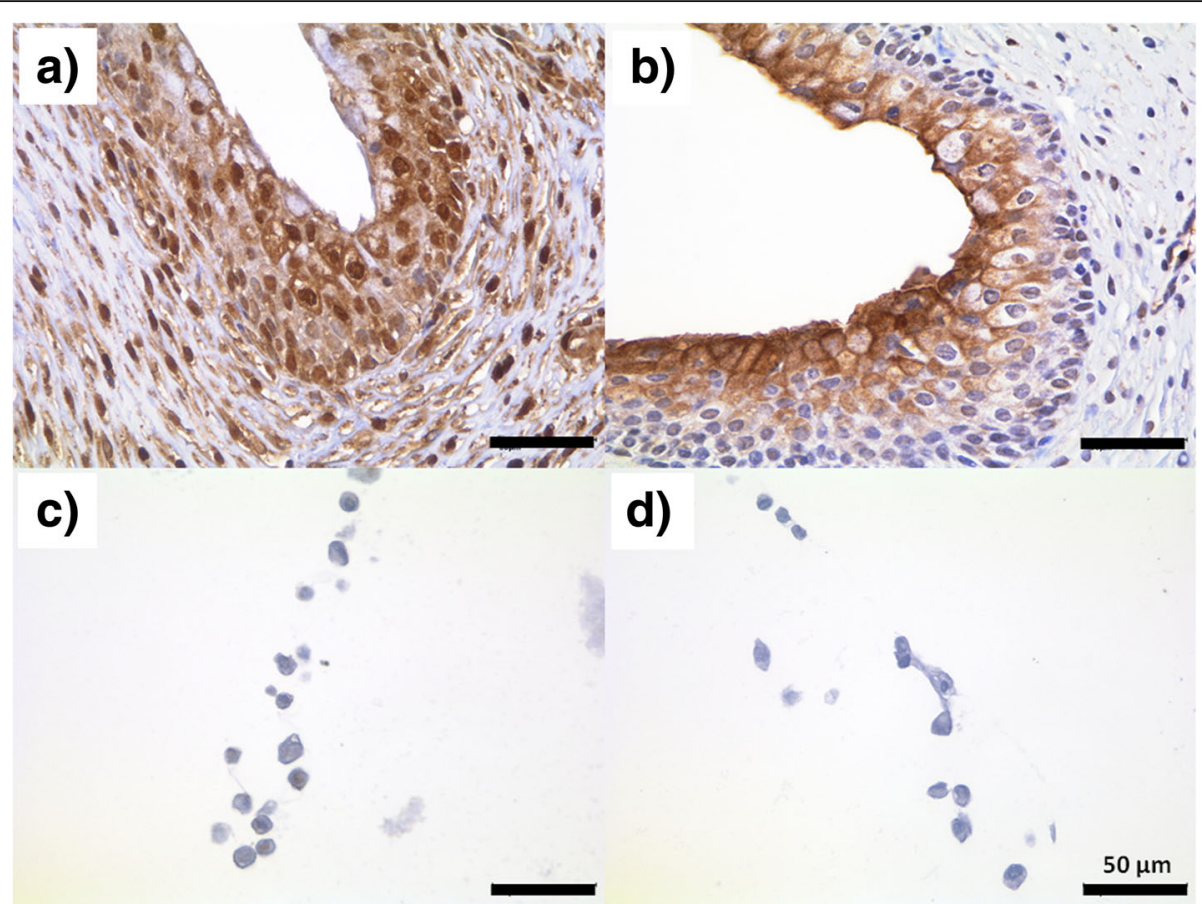

Fig. 2 Immunohistochemical staining of muscarinic receptors in native bladder tissue and derived urothelial cells. a+c Muscarinic receptor M2 and $\mathbf{b}+\mathbf{d} \mathrm{M} 3$ could be visualized in $\mathbf{a}+\mathbf{b}$ native bladder tissue of the German Landrace pig but $\mathbf{c}+\mathbf{d}$ not in the derived urothelial cells at passage 1. Scale bar $=50 \mu \mathrm{m}$

So far, we have only established the M2 and M3 immunohistostaining for the targets also analysed via qRT-PCR. As it is not easy to find antibodies that are applicable for pig tissue, it is often necessary to use antibodies for human or other species and hope for crossreactions. Therefore, we also tried a GAPDH antibody which turned out to react very unspecific. As the use of immune staining is more for visual effects, we postponed the establishment of other antibodies.

Using qRT-PCR expression analysis of selected enzymes, transporters and receptors of the urothelial cholinergic system, a comparable expression pattern was detected in the pig in the present study, as has previously been described for humans $[13,15,18,19]$. Although VAChT is an important vesicular transporter for ACh, it could not be detected in the porcine urothelium. This too, is in accordance with the findings in the human urothelium, where the presence of VAChT could not be proved [15]. However, as a limitation it has to be mentioned that the gene expression assay for VAChT was derived from a predicted cDNA sequence (see Table 1) and could not be confirmed in any porcine
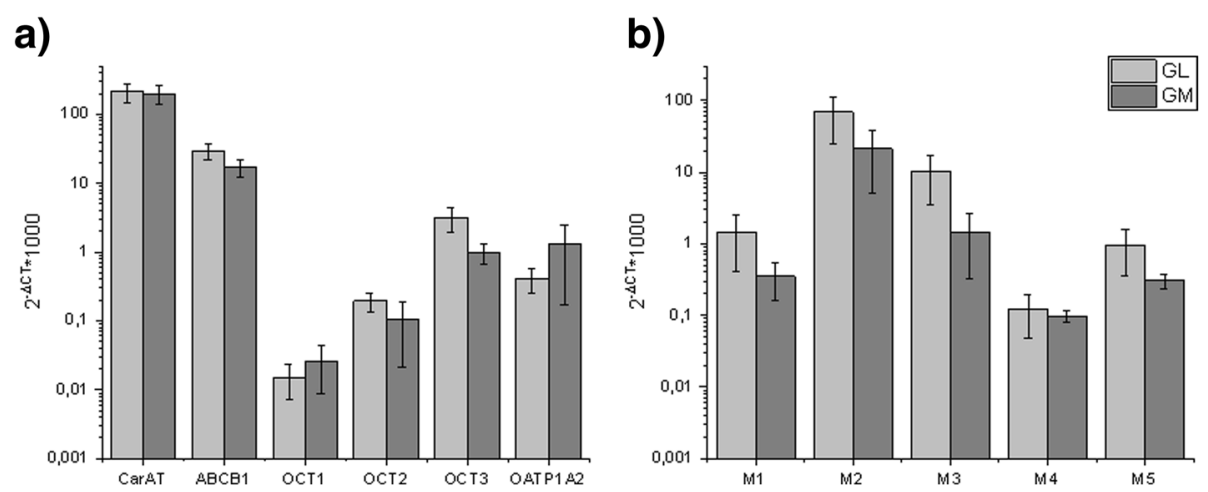

Fig. 3 Relative gene expression in the urothelium of German Landrace pigs and Göttingen minipigs $(n=3)$. VAChT and ChAT expression could not be detected. All enzymes/transporters (a) as well as receptors (b) relevant for anticholinergic therapy showed comparable expression pattern for GL and GM. Highest expression was detected for CarAT, ABCB1, OCT3, OATP1A2, M2 and M3. GAPDH expression was used for normalization 

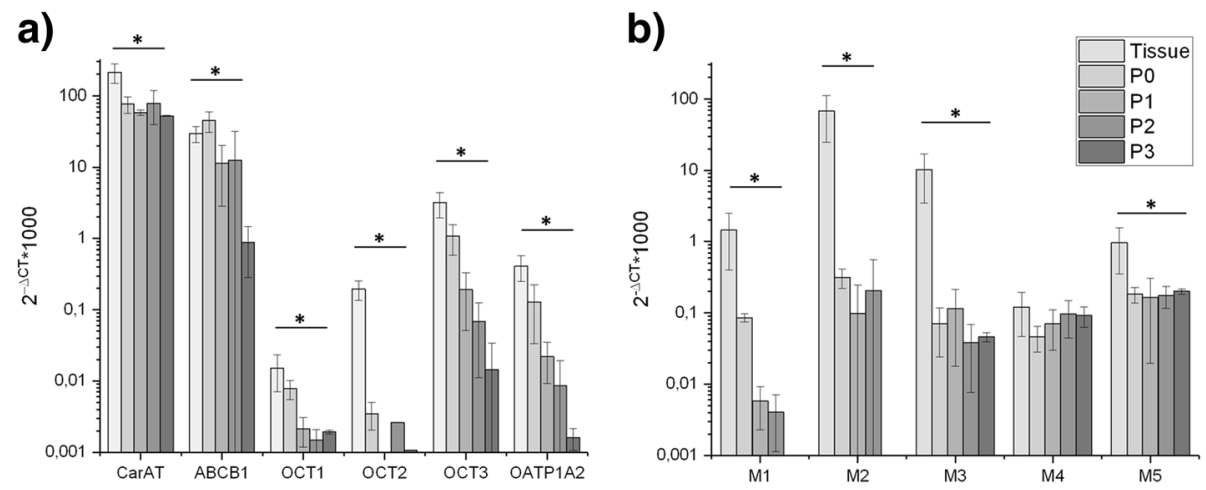

Fig. 4 Relative gene expression in the urothelium from German Landrace pigs ("Tissue") as well as derived UCs ("P0-P3") ( $n=3$ ). All enzymes/ transporters (a) as well as receptors (b) relevant for anticholinergic therapy were down-regulated during repeated passaging, with the exception of M4. In particular, expression levels of OCT2 and M1 dramatically dropped to nearly undetectable levels. GAPDH expression was used for normalization. * Significant down-regulation compared to tissue with $p<0.05$

tissue so far. Additionally, in the present study, expression of the classical ACh synthesising enzyme ChAT could not be detected in the porcine urothelium as has previously been reported for the human [13]. However, the porcine urothelium showed high mRNA expression levels for CarAT, which is an alternative source of ACh synthesis in the urothelium [13]. In the pig, all three OCTs (OCT1-3) were detected in the urothelium in the order OCT $3>$ OCT $2>$ OCT1, and all of them were also present in the human urothelium [13]. The solute carrier OATP1A2, uptake carrier for endogenous substances and pharmaceuticals in the human urothelium, has been identified as a transporter for TrCL by Bexten et al. [19], and could also be detected in the pig urothelium by our group. ABCB1 plays an important role in the efflux of many drugs, also including the anticholinergic drug TrCL [23]. ABCB1 is highly expressed in normal human urothelium $[18,19]$ and the present study also confirmed its expression in the porcine urothelium. Finally, all $5 \mathrm{M}$-receptors have been reported in the human urothelium $[13,14]$, and could be detected in the present study with a similar expression pattern in the pig, with the highest expression levels for M2 and M3.

Two different pig races were analysed i.e. GL and GM, and both showed comparable expression patterns to each other and the human. Taking this into account, it could be expected that pharmacological studies in pigs, for example with anticholinergic drugs, would substantially reflect the situation in man.

Cultivation of urothelial cells has previously been established in order to avoid repeated in vivo experiments in pigs, and to enable in vitro studies with urothelial derived cells. For this reason, the expression of the relevant enzymes, transporters, and receptors was also analysed under cell culture conditions during repeated passaging. Unfortunately, most of the analysed targets revealed continuous downregulation over time, which in general limits the usability of these cells, for example, for transport or receptor binding experiments at higher passaging frequencies. Bexten et al. were able to show that, on the one hand, TrCL is a substrate of the aforementioned solute carriers OCT1 and OATP1A2 (uptake), but on the other hand also for the efflux carrier ABCB1 [19]. The in vitro downregulation of the uptake transporters in combination with the still relatively high amount of the ABCB1 efflux carrier would lead to a non-physiological shift compared to the actual in vivo situation. This cultivation-related downregulation could also be observed for the muscarinic receptors, especially M2 and M3, which play a crucial role in the storing and voiding mechanisms of the bladder. M3 is known to mediate the contractile response and thus is addressed by the main muscarinic receptor antagonist TrCL [12]. This has to be considered for uptake studies with anticholinergic drugs like TrCL. However, downregulation of M1-M5 has also been demonstrated for human urothelial cells in culture by Tyagi et al. [14].

Interestingly, ABCB1 showed slight upregulation during the first round of cultivation in comparison to the tissue samples. This upregulation of ABCB1 might be triggered by cell culture supplements such as antibiotics, as the main role of this transporter is the efflux of potential hazardous substances out of the cell [23, 24].

UCs in culture are a promising model for pharmacological in vitro studies with anticholinergic drugs. However, such studies would be disadvantaged by downregulation of relevant transporters and receptors for ACh and / or anticholinergic drugs. Nevertheless, Mukerji et al. [25], as well as Gupta et al. [26], could show that urothelial cells of patients with interstitial cystitis (IC) retained their phenotype under cell culture conditions. Furthermore, the animals in this study were mature but not old [27, 28] and thus, do not represent the aged population which suffer from bladder dysfunctions. Therefore, a corresponding animal model with IC 
or $\mathrm{OAB}$ could provide more insight in the mechanisms of these diseases at a molecular level.

It remains that physiological and pharmacological studies on the urinary bladder are mainly conducted in rodent models [29-32]. These animals are cheap, easy to handle, and a large number of individuals can be investigated. However, data generated in rodents may not be fully comparable to the situation in humans, as the anatomy, physiology and the day-night-rhythm of these animals is somewhat different. Therefore, pigs were analysed in the present study as these show a more comparable bladder physiology to humans [4].

Initially the study was intended only with GL pigs as these are cheaper to obtain and therefore used more commonly in animal studies. Additionally, it is common practice to perform whole bladder experiments and drug studies using pig bladders from an abattoir [1-3, 33]. However, the GM has proven itself to be a comparable animal model for urological in vivo long-term studies, not only on the physiological [4] but also on the molecular level, as was also demonstrated in the present study. Based on the data presented here, both pig races are appropriate as a pharmacological animal model concerning the investigated targets.

\section{Conclusions}

This study was able to show that the porcine urothelium of the GL and GM pig is very similar to the human urothelium concerning the investigated ACh-dependent targets. We therefore conclude that both pig races are appropriate as a pharmacological animal model for in vivo and ex vivo investigations. Nevertheless, the use of UCs from healthy animals is limited due to the downregulation of the afore-mentioned targets. Therefore, the development and use of an animal model with OAB or IC could provide more insight into the working mechanism of these diseases.

\section{Abbreviations \\ ABCB1: ATP-binding cassette B1; ACh: Acetylcholine; CarAT: Carnitine acetyl- transferase; ChAT: Choline acetyl transferase; GAPDH: Glyercinaldehyde-3- phosphate-dehydrogenase; GL: German Landrace pig; GM: Göttingen Minipig; IC: Interstitial cystitis; M1-5: Muscarinic receptors 1-5; MEM: Modified Eagle's Medium; OAB: Overactive bladder; OATP1A2: Organic anion transporting polypeptide 1A2; OCT1-3: Organic cation transporters 1-3; PBS: Phosphate buffered saline; TrCL: Trospium chloride; UC: Urothelial cell; VAChT: Vesicular acetylcholine transporter}

\footnotetext{
Acknowledgements

The authors thank the research group of the Department of Urology, especially Katja Stollenwerk and Mykhailo Reidman for technical support, and the Institute of Laboratory Animal Sciences at RWTH Aachen University Hospital especially Taddhäus Stopinski for excellent animal care. Furthermore, we thank Stephanie Schmidt of the Institute of Pharmacology and Toxicology, Giessen for her scientific input. This work was also supported by the Cell Culture Facility, a Core Facility of the Interdisciplinary Center for Clinical Research (IZKF) Aachen within the Faculty of Medicine at RWTH Aachen University.
}

\section{Authors' contributions}

All authors have made substantial contributions to conception and design acquisition of data, or analysis and interpretation of data: $\mathrm{DL}$ designed the study, performed the experiments and analysed the data, JK performed the experiments and analysed the data, RL and PA performed the experiments JG and JOG designed the study and analysed the data. US, as an employee of the sponsor, was involved in the determination of the study design, but had no control over the study conduct, or the collection and analysis of data. All authors have been involved in drafting the manuscript or revising it critically for important intellectual content; All authors have given final approval of the version to be published and take public responsibility for appropriate portions of the content. All authors have agreed to be accountable for all aspects of the work in ensuring that questions related to the accuracy or integrity of any part of the work are appropriately investigated and resolved. The authors have read and approve of the final version.

\section{Funding}

This study was funded by the Dr. R. Pfleger GmbH, Germany. The Dr. R. Pfleger $\mathrm{GmbH}$ had no control over the study conduct, or the collection and analysis of the data.

\section{Availability of data and materials}

The datasets used and/or analysed during the current study are available from the corresponding author on reasonable request.

\section{Ethics approval and consent to participate}

All projects for which our study group received subordinate urinary bladder material were either notified or approved by our licensing authority, the LANUV (Landesamt für Natur-, Umwelt und Verbraucherschutz in

Recklinghausen). The secondary use of tissues or organs from dead animals does not require approval by the authorities according to animal welfare regulations in Germany.

\section{Consent for publication}

Not applicable.

\section{Competing interests}

$\mathrm{DL}, \mathrm{JK}, \mathrm{RL}, \mathrm{PA}, \mathrm{JG}$, and JOG declare that they have no competing interests. US is an employee of Dr. R. Pfleger GmbH, Bamberg.

\section{Author details}

'Department of Urology, RWTH Aachen University Hospital, Pauwelsstraße 30, 52074 Aachen, Germany. ${ }^{2}$ Institute of Pharmacology and Toxicology, Biomedical Research Center BFS, Justus Liebig University Giessen, Giessen, Germany. ${ }^{3}$ Dr. R. Pfleger GmbH, Bamberg, Germany.

Received: 15 February 2018 Accepted: 4 July 2019

Published online: 09 July 2019

\section{References}

1. Templeman L, Chapple CR, Chess-Williams R. Urothelium derived inhibitory factor and cross-talk among receptors in the trigone of the bladder of the pig. J Urol. 2002;167(2):742-5.

2. Yamanishi T, Chapple CR, Yasuda K, Chess-Williams R. The role of M-2muscarinic receptors in mediating contraction of the pig urinary bladder in vitro. Br J Pharmacol. 2000;131(7):1482-8.

3. Parsons BA, Drake MJ, Gammie A, Fry CH, Vahabi B. The validation of a functional, isolated pig bladder model for physiological experimentation. Front Pharmacol. 2012:3:52.

4. Huppertz ND, Tolba RH, Grosse JO. Micturition in Gottingen minipigs: first reference invivo data for urological research and review of literature. Lab Anim. 2015;49(4):336-44.

5. Bode G, Clausing P, Gervais F, Loegsted J, Luft J, Nogues V, et al. The utility of the minipig as an animal model in regulatory toxicology. J Pharmaco Toxicol Methods. 2010;62(3):196-220.

6. Abrams $P$, Andersson KE. Muscarinic receptor antagonists for overactive bladder. BJU Int. 2007;100(5):987-1006.

7. Andersson KE, Yoshida M. Antimuscarinics and the overactive detrusor which is the main mechanism of action? Eur Urol. 2003;43(1):1-5.

8. Abrams P, Andersson KE, Buccafusco JJ, Chapple C, de Groat WC, Fryer $A D$, et al. Muscarinic receptors: their distribution and function in body 
systems, and the implications for treating overactive bladder. $\mathrm{Br} \mathrm{J}$ Pharmacol. 2006;148(5):565-78.

9. Finney SM, Andersson KE, Gillespie Jl, Stewart LH. Antimuscarinic drugs in detrusor overactivity and the overactive bladder syndrome: motor or sensory actions? BJU Int. 2006;98(3):503-7.

10. Goepel M, Gronewald A, Krege S, Michel MC. Muscarinic receptor subtypes in porcine detrusor: comparison with humans and regulation by bladder augmentation. Urol Res. 1998;26(2):149-54.

11. Sellers DJ, Yamanishi T, Chapple CR, Couldwell C, Yasuda K, Chess-Williams R. M-3 muscarinic receptors but not M-2 mediate contraction of the porcine detrusor muscle in vitro. J Auton Pharmacol. 2000;20(3):171-6.

12. Mansfield KJ, Liu L, Mitchelson FJ, Moore KH, Millard RJ, Burcher E. Muscarinic receptor subtypes in human bladder detrusor and mucosa, studied by radioligand binding and quantitative competitive RT-PCR: changes in ageing. Br J Pharmacol. 2005;144(8):1089-99.

13. Bschleipfer T, Schukowski K, Weidner W, Grando SA, Schwantes U, Kummer $W$, et al. Expression and distribution of cholinergic receptors in the human urothelium. Life Sci. 2007;80(24-25):2303-7.

14. Tyagi S, Tyagi P, Van-le S, Yoshimura N, Chancellor MB, de Miguel F. Qualitative and quantitative expression profile of muscarinic receptors in human urothelium and detrusor. J Urol. 2006;176(4).

15. Lips KS, Wunsch J, Zarghooni S, Bschleipfer T, Schukowski K, Weidner W, et al. Acetylcholine and molecular components of its synthesis and release machinery in the urothelium. Eur Urol. 2007;51(4):1042-53.

16. Wenge $\mathrm{B}$, Geyer J, Bönisch $\mathrm{H}$. The anticholinergic drugs oxybutynin and trospium chloride are substrates of the human organic cation transporters In: Naunyn-Schmiedeberg's archives of pharmacology, vol. 383. Berlin Heidelberg: Springer; 2010. p. 203-8.

17. Franke RM, Scherkenbach LA, Sparreboom A. Pharmacogenetics of the organic anion transporting polypeptide 1A2. Pharmacogenomics. 2009;10(3):339-44.

18. Clifford SC, Neal DE, Lunec J. High level expression of the multidrug resistance (MDRI) gene in the normal bladder urothelium: a potential involvement in protection against carcinogens? Carcinogenesis. 1996;17(3):601-4.

19. Bexten M, Oswald S, Grube M, Jia J, Graf T, Zimmermann U, et al. Expression of drug transporters and drug metabolizing enzymes in the bladder Urothelium in man and affinity of the bladder spasmolytic Trospium chloride to transporters likely involved in its pharmacokinetics. Mol Pharm. 2015;12(1):171-8.

20. Leonhäuser D, Vogt M, Tolba RH, Grosse JO. Potential in two types of collagen scaffolds for urological tissue engineering applications - are there differrences in growth behaviour of juvenile and adult vesical cells? J Biomater Appl. 2016;30(7):961-73.

21. Birder LA. More than just a barrier: urothelium as a drug target for urinary bladder pain. Am J Physiol Renal Physiol. 2005;289(3):F489-F95.

22. Apodaca G. The uroepithelium: not just a passive barrier. Traffic. 2004;5(3):117-28.

23. Geyer J, Gavrilova O, Petzinger E. The role of P-glycoprotein in limiting brain penetration of the peripherally acting anticholinergic overactive bladder drug Trospium chloride. Drug Metab Dispos. 2009:37(7):1371-4

24. Oswald S, Grube M, Siegmund W, Kroemer HK. Transporter-mediated uptake into cellular compartments. Xenobiotica. 2007;37(10-11):1171-95.

25. Mukerji G, Yiangou Y, Grogono J, Underwood J, Agarwal SK, Khullar V, et al. Localization of $\mathrm{M}-2$ and $\mathrm{M}-3$ muscarinic receptors in human bladder disorders and their clinical correlations. J Urol. 2006;176(1):367-73.

26. Gupta GN, Lu SG, Gold MS, Chail TC. Bladder urothelial cells from patients with interstitial cystitis have an increased sensitivity to carbachol. Neurourol Urodyn. 2009:28(8):1022-7.

27. Vahabi B, Sellers DJ, Bijos DA, Drake MJ. Phasic contractions in urinary bladder from juvenile versus adult pigs. Plos One. 2013;8(3).

28. Bollen $\mathrm{P}$, Ellegaard $\mathrm{L}$. The Gottingen minipig in pharmacology and toxicology. Pharmacol Toxicol. 1997:80:3-4.

29. Zarghooni S, Wunsch J, Bodenbenner M, Brueggmann D, Grando SA, Schwantes $U$, et al. Expression of muscarinic and nicotinic acetylcholine receptors in the mouse urothelium. Life Sci. 2007:80(24-25).

30. Hanna-Mitchell AT, Beckel JM, Barbadora S, Kanai AJ, de Groat WC, Birder LA. Non-neuronal acetylcholine and urinary bladder urothelium. Life Sci. 2007;80(24-25):2298-302

31. Matsumoto Y, Miyazato M, Furuta A, Torimoto K, Hirao Y, Chancellor MB, et al. Differential roles of M2 and M3 muscarinic receptor subtypes in modulation of bladder afferent activity in rats. Urology. 2010;75(4):862-7.

32. Nandigama R, Ibanez-Tallon I, Lips KS, Schwantes U, Kummer W, Bschleipfer $\mathrm{T}$. Expression of nicotinic acetylcholine receptor subunit mRNA in mouse bladder afferent neurons. Neuroscience. 2013;229:27-35.
33. Williams NA, Lee KM, Allender CJ, Bowen JL, Gumbleton M, Harrah T, et al. Investigating detrusor muscle concentrations of oxybutynin after Intravesical delivery in an ex vivo porcine model. J Pharm Sci. 2015;104(7):2233-40.

\section{Publisher's Note}

Springer Nature remains neutral with regard to jurisdictional claims in published maps and institutional affiliations.
Ready to submit your research? Choose BMC and benefit from:

- fast, convenient online submission

- thorough peer review by experienced researchers in your field

- rapid publication on acceptance

- support for research data, including large and complex data types

- gold Open Access which fosters wider collaboration and increased citations

- maximum visibility for your research: over $100 \mathrm{M}$ website views per year

At $\mathrm{BMC}$, research is always in progress.

Learn more biomedcentral.com/submissions 